\title{
Late angiographic evaluation of radial artery grafts used in surgical myocardial revascularization
}

\author{
Avaliação angiográfica tardia do enxerto de artéria radial na cirurgia de revascularização do \\ miocárdio
}

Siderval Ferreira ALVES ${ }^{1}$, Dolores Cristina M. ALBUQUERQUE ${ }^{1}$, Eraldo Antonio PELLOSO ${ }^{1}$, Wesley Ferraz SILVEIRA $^{1}$, Andre LABRUNIE ${ }^{1}$, Christiano Roberto BARROS ${ }^{1}$, Rubens T. BARROS ${ }^{1}$, Antonio C. PENNA ${ }^{1}$

RBCCV 44205-618

\section{Abstract:}

Objective: To evaluate the late patency of the radial artery used as a conduit in coronary artery bypass grafting through a selective catheterization.

Method: A group of 109 patients operated on for coronary artery bypass grafting used radial artery as grafts, from September 1995 to October 1996, were re-studied in the immediate post-operative period. Among these patients, 91 $(83.5 \%)$ were contacted either by phone or through outpatient follow-ups, and 34 underwent a late angiographic study. Twenty-two patients were male $(65 \%)$. The average age of the patients was 57.4 years old (37-70). The average time of the restudy was of 51.2 months (41-63). Thirty-eight distal anastomoses were performed using the radial artery, with an average of 1.12 distal anastomoses per patient. The analysis of these data is the basis for the present study.

Results: The radial artery was patent in 30 patients $(34$ distal anastomoses $-89.5 \%$ ), and had a lesion in only one patient along with the proximal anastomosis in the aorta. Out of the four patients who presented total graft obstruction, two were male. We observed inadequate indications in two patients, and no justifiable occlusions in the others. From the 91 re-studied patients in the immediate post-operative period, there was late mortality in 6 patients $(6.6 \%)$, one adenocarcinoma of the lung, and the others by cardiac causes. The only patient who presented a lesion at the radial artery underwent angioplasty with a stent implantation and had a satisfactory outcome.

Conclusions: The radial artery, used as a conduit for coronary artery bypass grafting, shows satisfactory angiographic aspects and also a satisfactory patency, similar to those of the left internal thoracic artery, when evaluated in this time of follow-up.

Descriptors: Radial artery, surgery. Radial artery, anatomy and histology. Myocardial revascularization.

\section{Resumo}

Objetivos: Avaliar a patência tardia da artéria radial (AR), utilizada como enxerto na revascularização do miocárdio (RM), por meio de estudo cineangiocoronariográfico.

Work performed in the ICM (Heart Institute of Marília), Hospital

Santa Casa de Misericórdia of Marília. Marília, SP, Brazil.

1 from ICM- Heart Institute of Marília.

Correspondence address:

Siderval Ferreira Alves.

Rua Paulo da Cunha Matos, 447.

Marília, SP

CEP: $17516-430$.

Tel: (14) 422-4872. e-mail: siderval.icm@icm.com.br 
Método: Um grupo de 109 pacientes operados para RM, que utilizaram AR, no período de setembro de 1995 a outubro de 1996, foi reestudado no período pós-operatório imediato. Desses pacientes, $91(83,5 \%)$ puderam ser contatados por telefone e/ou retorno ambulatorial e 34 submeteram-se a reestudo cineangiocoronariográfico tardio. Vinte e dois $(65 \%)$ pacientes eram do sexo masculino; a idade média do grupo, na época da operação era 57,4 anos (37-70), o tempo médio de reestudo foi de 51,2 meses (41-63). Trinta e oito anastomoses distais foram realizadas utilizando-se a AR, com média de 1,12 anastomoses distais por paciente. $A$ análise dos exames constitui a base do presente trabalho.

Resultados: A AR estava pérvia em 30 pacientes (34 anastomoses distais-89,5\%) e com lesão em apenas um paciente, junto à anastomose proximal na aorta. Dos quatro pacientes que apresentavam obstrução total do enxerto,

\section{INTRODUCTION}

With the aim of avoiding early reoperations in coronary artery bypass grafting $(\mathrm{CABG})$ for occlusion of the venous grafts, new arterial grafts have started awakening new interest.

The left internal thoracic artery (LITA) is the most frequently utilized in CABG, and its patency is reported to be at $90 \%$ or more at ten years after surgery $[1,2]$.

Some authors have already reported more advantages using an arterial graft in CABG than the advantages verified in patients who received venous grafts. Individuals who received the LITA had a greater survival rate, a lower incidence of reoperations and acute myocardial infarction and fewer hospitalizations for cardiac events [3,4]. More recently, it was demonstrated that the growth of a second arterial graft in $\mathrm{CABG}$ proved to be more efficient than the use of only an arterial graft, the LITA [5].

The radial artery (RA) for CABG was first introduced by Carpentier et al. [6] in 1073, and completely abandoned in 1976 after early angiographic studies demonstrated a high incidence of occlusion of the graft $[7,8]$.

In 1989, Acar et al. [9] reintroduced the use of the RA in $\mathrm{CABG}$ after receiving angiographic data of the late patency of RAs implanted in the 1970s. Since then, the RA has had growing interest and in several departments it is routinely being used.

This work aims at reporting the early and late angiographic data of patients submitted to $C A B G$ in which the RA was used as a graft.

\section{METHOD}

metade do sexo masculino, observamos indicação inadequada em dois deles e, nos demais, sem justificativa para as oclusões. Dos 91 pacientes reestudados no período pós-operatório imediato, houve mortalidade tardia em seis $(6,6 \%)$ pacientes, um por adenocarcinoma de pulmão, os outros por prováveis causas cardíacas. $O$ único paciente que apresentou lesão na AR foi submetido à angioplastia com implante de stent, com bom resultado.

Conclusões: $O$ enxerto de artéria radial, para cirurgia de revascularização do miocárdio, apresenta bons aspectos angiográficos e boa patência, semelhantes aos da artéria torácica interna esquerda com esse tempo de avaliação.

Descritores: Artéria radial, cirurgia. Artéria radial, anatomia e histologia. Revascularização miocárdica.

From September 1995 to October 1996, 109 patients underwent $\mathrm{CABG}$ using the RA and were restudied between six and 18 days after (mean 15 days). The mean age of the patients was $57.5 \pm 8.2$ years, varying from 34 to 75 years. The risk factors for coronary disease were systemic arterial hypertension (51\%), type II diabetes mellitus (20\%), previous acute myocardial infarction $(60 \%)$ and associated procedures (5\%).

Of these 109 patients, 91 (89.5\%) were contacted by telephone or in the outpatients clinic and after explaining the objective of this study, a new late angiographic study was proposed for all the surviving patients. The angiography was only performed with the consent of the patients and with the approval of the Institution's Research Ethical Committee. A total of 34 patients agreed with the late coronary cineangiography restudy. The angiography was performed between 41 and 63 months after the operation (mean $51.2 \pm 4.9$ months). The ages of these patients varied between 37 and 70 years (average of $57.4 \pm 8.0$ years). Twenty-two of the patients were male and 12 female.

The angiographic procedure was performed by puncture of the left femoral artery or dissection of the left brachial artery, utilizing a Sones or Amplatz catheter, or a mammary catheter when the patient had a internal thoracic artery graft. A non-ionic contrast was used for the internal thoracic artery and ionic for the others.

\section{Surgical technique}

The modified Allen test was performed before the removal of the RA. When positive, other tests (Doppler ultra-sound, Allen test with oximeter) were performed to 
assess the perfusion to the hand by the ulnar artery. When the tests confirmed a good perfusion, the RA was used for the graft.

All the patients were operated on by median sternotomy followed by pericardiotomy. After heparin therapy using $4 \mathrm{mg} / \mathrm{kg}$ weight, a catheter was inserted in the ascending aorta and venous drainage was achieved by a single catheter in the right atrium. After the installation of the cardiopulmonary bypass, all patients were submitted to hypothermia of $32{ }^{\circ} \mathrm{C}$, total and continuous clamping of the aorta with myocardial protection achieved using cardioplegia (Braile Biomedica - solution for low volume blood cardioplegia).

Dissection of the RA was performed using little electrocauterization with a low voltage, and avoiding contact. When the entire section of the RA was freed and legation of the proximal pedicle was performed, it was sectioned. Following this, $10 \mathrm{ml}$ of blood was drawn by retrograde flux and $50 \mathrm{ml}$ of $0.9 \%$ saline solution, $0.5 \mathrm{ml}$ of heparin (2500U), $1 \mathrm{ml}(2.5 \mathrm{mg}$ ) of Verapamil and $1 \mathrm{ml}$ (50 $\mathrm{mg}$ ) of papaverine were added. After the proximal RA was catheterized provoking occlusion of the distal section and $20 \mathrm{ml}$ of the solution at a low pressure was injected, reversing the spasms that occur in nearly $100 \%$ of the RA, by all dissection techniques employed. The graft was then checked and legation of its branches using 4.0 cotton thread or metal clips was made. Following this the graft was immersed in the same solution until its utilization.

The site of the anastomosis of the RA was always the ascending aorta. A calcium channel blocker (Verapamil) at $0.1 \mathrm{mg} / \mathrm{kg} / \mathrm{h}$ was endovenously administered in the intra- and post-operative periods until 36 hours in the intensive care unit (ICU) and after Diltiazen $180 \mathrm{mg} /$ day, via oral during six months was used.

The average number of grafts was $2.74 \pm 0.8$ per patient (a range of one to five grafts per patient). These included a total of 93 distal anastomoses, 38 of the RA, 27 of the LITA in situ, two of the right internal thoracic artery (RITA) in situ and 26 of the saphenous vein.

The implantation sites of the RA, LITA, RITA and the saphenous vein are demonstrated in Table 1.

Table 1. Grafted coronary artery and number of grafts used

\begin{tabular}{lcccc}
\hline & $\begin{array}{c}\text { Radial } \\
\text { Artery }\end{array}$ & $\begin{array}{c}\text { Left internal } \\
\text { Thoracic artery }\end{array}$ & $\begin{array}{c}\text { Saphenous } \\
\text { Vein }\end{array}$ & $\begin{array}{c}\text { Right internal } \\
\text { Thoracic artery }\end{array}$ \\
\hline Anterior Descending & 3 & 23 & 1 & 0 \\
Diagonal & 10 & 2 & 8 & 0 \\
Diagonalis & 3 & 1 & 0 & 0 \\
Circumflex Marginal & 11 & 1 & 11 & 0 \\
Right Coronary & 11 & 0 & 6 & 2 \\
TOTAL & 38 & 27 & 26 & 2 \\
\hline
\end{tabular}

Associated procedures were performed in five patients all for the correction of left ventricle aneurysms.

The ages, times of the early and late restudies were summarized as the mean \pm standard deviation and patencies as percentages. The exact Fisher test was used for comparisons between groups for the results of patency of the grafts in the early and late studies, where a level of significance of 5\% was adopted for the rejection of the null hypothesis.

\section{RESULTS}

When the early restudy of the 109 patients was performed, 301 distal anastomoses were made, with $2.76 \pm$ 0.8 grafted arteries per patient, the patency of the RA was 96.7\% (118/122), LITA in 95.3\% (102/107), saphenous vein in $90.2 \%(59 / 65)$ and RITA in $100 \%$ (7/7). Also an incidence of $22 \%$ (27 grafts) of spasms were observed in the RA grafts, where narrowing of the RA at less than 50\% was more commonly observed in 18 patients. The 'string sign' (diffuse narrowing greater than $50 \%$, present in the entire segment of the RA) was observed in 5 patients. Local narrowing, less than $50 \%$, was seen in four patients. All the grafts without spasms presented with good angiographic aspects, with diameters almost always a little greater than the grafted coronary artery [10]. Comparing the patency of the grafts in the early study of the 109 patients between the RA and LITA, it was from $96.7 \%$ and $95.3 \%$, respectively (p-value $=$ 0.42 ) and between the RA of $96.7 \%$ and the saphenous vein of $90.2 \%$ (p-value $=0.086$ ).

When we only analyzed the 34 patients in the early study who were also submitted to the late study, we observed that, in the early study, all the RAs were pervious. Thirtyeight distal anastomoses were performed utilizing the RA, a mean of 1.12 anastomoses per patient, the patency of the LITA was $96.3 \%$ (26/27), the saphenous vein was $88.5 \%$ (23/ 26 ) and the RITA was $100 \%$ (2/2). Eleven (28.9\%) of the RA grafts presented with spasms; narrowing of the RA was less than 50\% in seven grafts, greater than 50\% and local in three grafts and in one graft, diffuse narrowing greater than $50 \%$ along the entire extension of the RA graft was observed. In the LITA graft, three (11.1\%) presented with spasms; one with diffuse narrowing greater than 50\% along the entire extension, two with local narrowing less than $50 \%$ and one with a probable hematoma in the middle third.

Comparing the patency of the grafts in the early study between the RA and LITA, from $100 \%$ and $96.3 \%$, respectively (p-value $=0.41$ ) and between RA of $100 \%$ and the saphenous vein of $88.5 \%$ (p-value $=0.062$ ) - Figure 1 .

In the late study of 34 patients, the RA was pervious in 30 patients $89.5 \%$ (34/38), the LITA in $88.9 \%$ (24/27), the saphenous vein in 77\% (20/26) and the RITA in 1005 (2/2). 


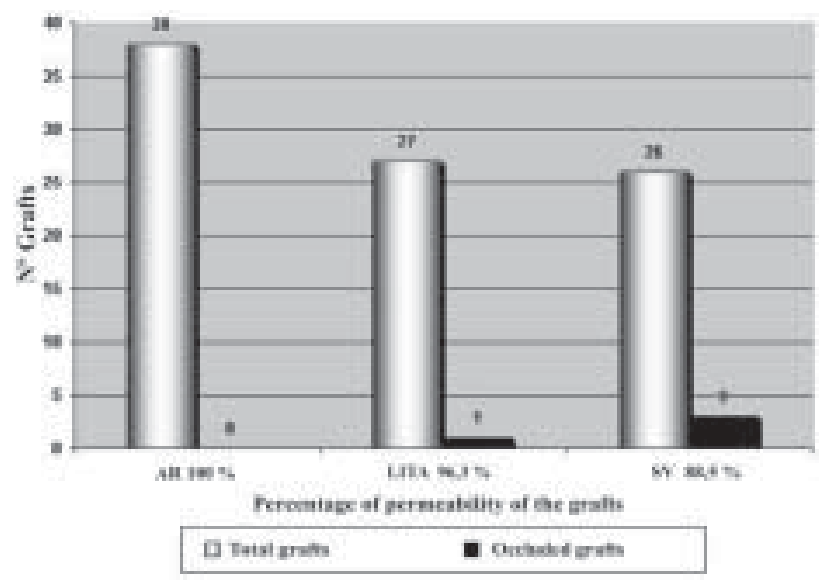

Fig. 1 -Result of the patency of the grafts in the early restudy

In one RA graft a lesion beside the anastomosis in the aorta was observed and the patient was submitted to an angioplasty with a good outcome.

The angiographic study is the best examination, capable of analyzing the characteristics of the grafts, with the patency being the criterion of success [11]. Figure 2 compares the patency of the grafts in the late study, between the RA $(89.5 \%)$ and the LITA $(88.9 \%)$ with a p-value $=0.68$ and between the RA ( $89.5 \%)$ and the saphenous vein $(77 \%)$ with a p-value $=0.15$.

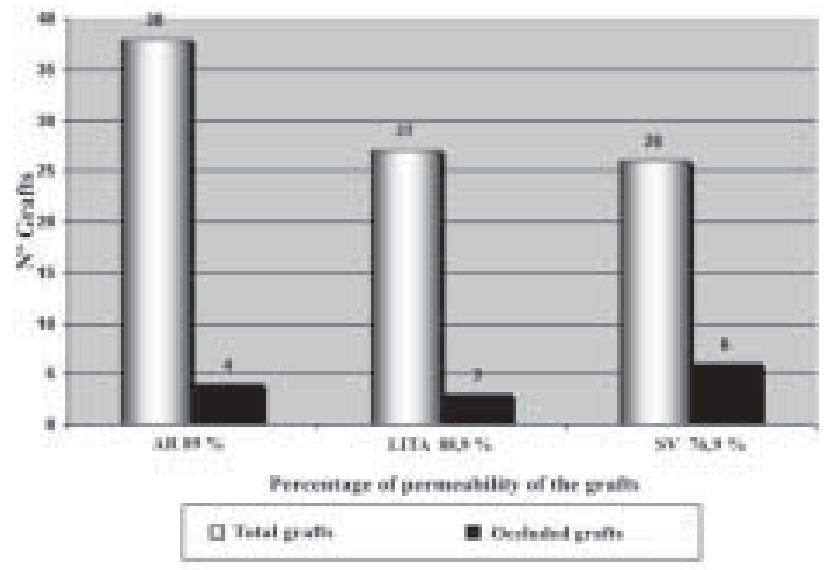

Fig. 2 - Result of the patency of the grafts in the late restudy

In four $(10.5 \%)$ patients with total obstruction of the graft, one presented a lesion of the mid-third of the right coronary artery in the pre-operative coronary cineangiography. However in the early study, 10 days after grafting, the RA was observed to be with a good permeability and the right coronary artery without lesion. In the late study (at 54 months), the RA was found to be occluded (Figure 3).

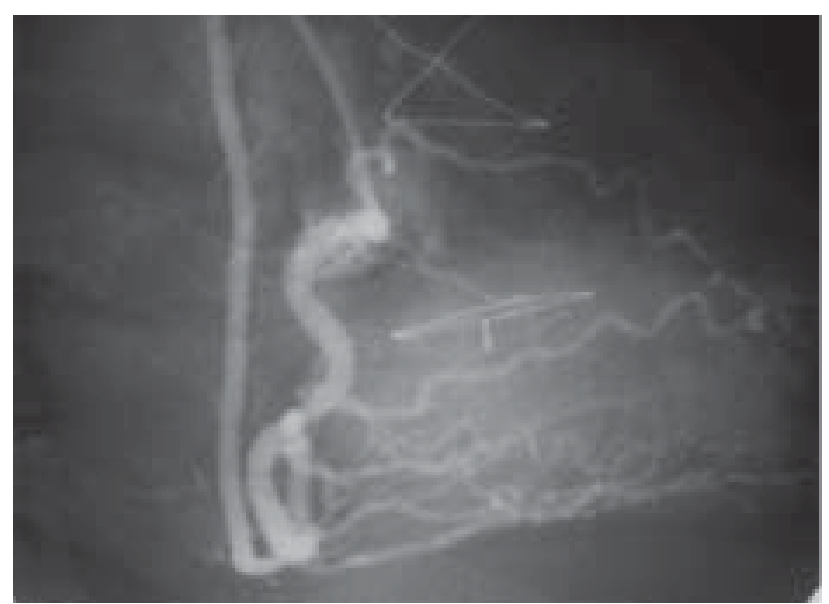

Fig. 3 a - early restudy - 10 days after myocardial revascularization

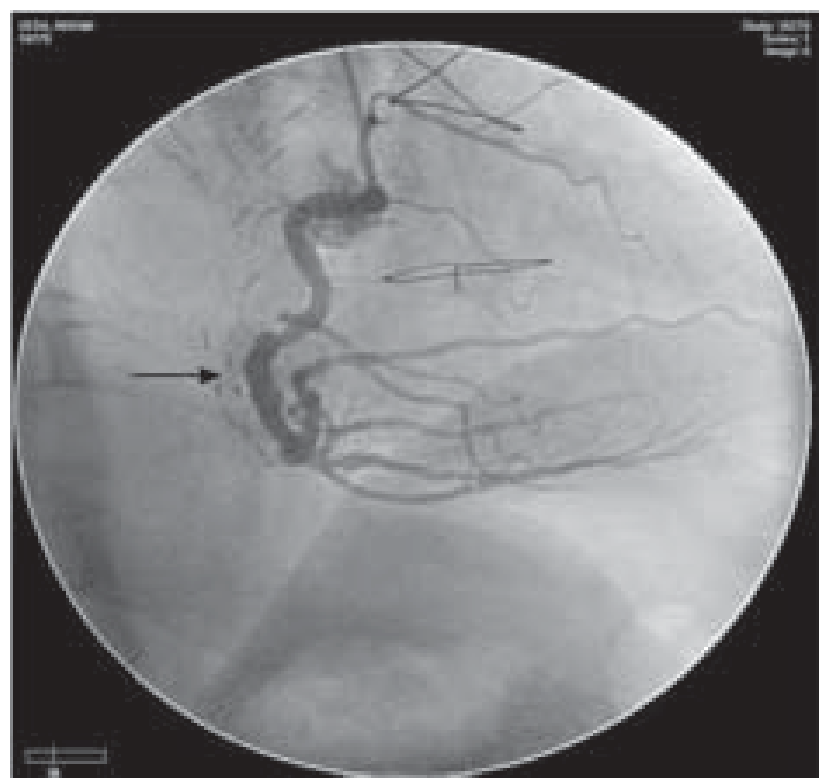

Fig. $3 b$ - late restudy - 54 months after myocardial revascularization ( $R A$ closed)

In another patient, the RA was seen to be with spasms (string sign) in the early study at 14 post-operative days and the marginal coronary artery without lesions. In the late study (at 62 post-operative months), the RA was occluded and the marginal coronary artery without obstructive lesion 
(Figure 4). In these two patients, the occlusion occurred probably due to competitive flow, however occlusion probably occurred due to a bad distal flow in one other and without apparent cause in a fourth.

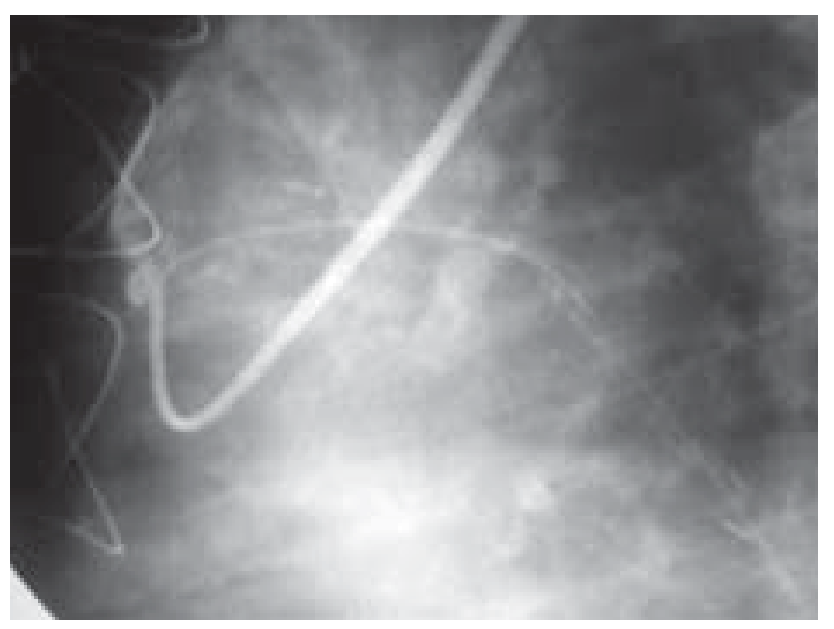

Fig. 4 a - early restudy - 14 days after myocardial revascularization (RA String Sign)

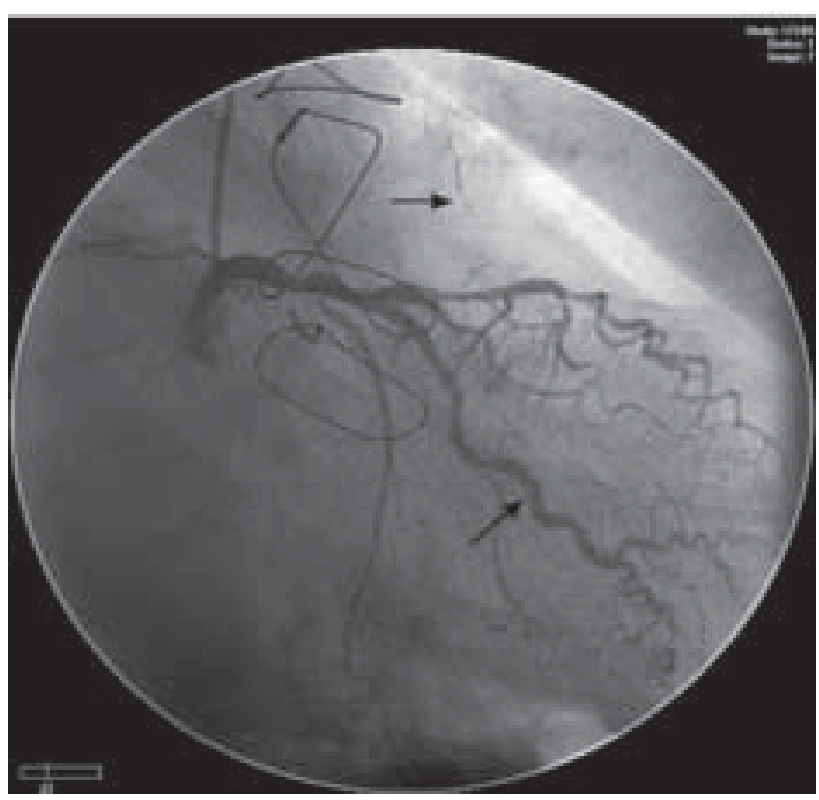

Fig. $4 b$ - late restudy - 62 months after myocardial revascularization (Mg Artery without obstructive lesion)

In relation to the LITA there were three occlusions. One early without an apparent cause and two in the late study period also probably due to competitive flow, as in the late study the grafted arteries (DA) presented with a good permeability, with a good diameter and with lesions of 50\% or less of the lumen.
In the late study of the RA, no type of spasm was observed in the patent grafts and the angiogram presented a good aspect without lesions. All the grafts presented with diameters proportional to the distal segment of the grafted coronary artery. The LITA and RITA also presented with excellent angiographic aspects, without any alterations (spasms, irregularities of the walls), sometimes with a diameter greater than the distal segment of the grafted coronary artery. The same was not true for the saphenous vein grafts, some with disproportional diameters compared to the grafted coronary artery and others with irregularities of the vessel walls. These observations have already been cited in previous publications [12].

Of the 91 patients who were contacted by telephone, there were six (6.6\%) late deaths, one due to adenocarcinoma of the lung and the others probably with heart related causes. Four patients presented with angina, one with a lesion in the circumflex artery which was not grafted at the time of the surgery as it did not present with an obstructive lesion and three patients require further studies.

\section{COMMENTS}

In 1995 the use of the RA for CABG was initiated in our department and today we use it routinely. Today only the modified Allen test with oximeter of the wrist are performed to assess the blood supply to the hand by the ulnar artery, as it is a simple method, with good specificity and sensitivity. Only in 2\% of the patients the examination is positive [13].

To remove the RA, after the incision in the skin, all the dissection is performed by electrocauterization using a low voltage and avoiding contact with the RA, lateral antibrachial cutaneous nerves and the superficial branch of the radial nerve (Figure 5).

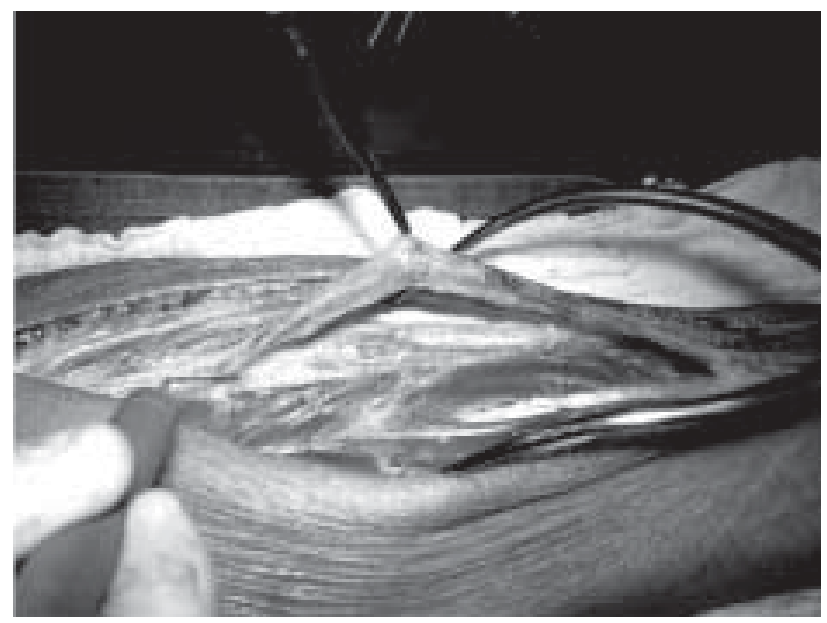

Fig. 5 -Dissection of the radial artery with electrocauterization 
The current mean of grafts per patient using the RA is from 1.8 distal anastomoses per patient. Today, whenever possible, a segment of the RA is anastomosed in a ' $\mathrm{Y}$ ' shape (Figure 6) with the LITA for a branch of the left coronary artery $(\mathrm{Dg}, \mathrm{Mg})$. It is also possible that two segments of the RA are anastomosed to the LITA thus, allowing in some cases, up to three distal anastomoses with only one RA and occasionally the two RAs are removed.

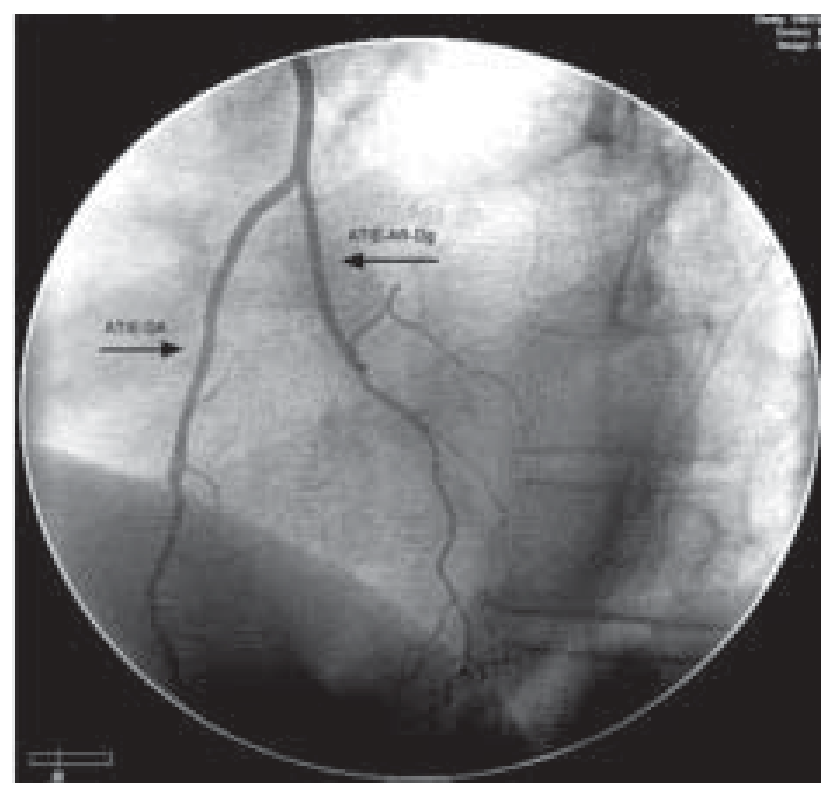

Fig 6 - Anastomoses in " $Y$ " shape Left internal thoracic arteryRadial artery

In our experience, we found early patency of the RA of $96.7 \%$ in 122 grafts studied and a late patency of $89.5 \%$ in 38 grafts. These obtained data are similar to data found in current publications demonstrated in Tables 2 and 3. Despite of not having statistical differences among the different graft types, the RA presented with a greater patency than the saphenous vein, which may prove to be statistically significant if the sample size were greater.

Table 2. Review of the literature about the early patency rate of the radial artery

\begin{tabular}{lcr}
\hline Year / Reference & AR grafts & Patent grafts \\
\hline 1992 Acar et al $^{(9)}$ & 56 & $56(100 \%)$ \\
1995 Calafiori et al $^{(14)}$ & 76 & $75(98.7 \%)$ \\
1996 Chen et al $^{(24)}$ & 94 & $90(95.7 \%)$ \\
1996 Da Costa et al $^{(25)}$ & 61 & $59(96.7 \%)$ \\
1997 Penna et al $^{(10)}$ & 122 & $118(96.7 \%)$ \\
\hline
\end{tabular}

$\mathrm{RA}=$ Radial artery
Table 3. Review of the literature about the late patency rate of the radial artery

\begin{tabular}{lcr}
\hline Year / Reference & AR grafts & Patent grafts \\
\hline 2002 Da Costa et al ${ }^{(16)}$ & 28 & $26(92.7 \%)$ \\
1998 Possati et al ${ }^{(21)}$ & 48 & $42(87.5 \%)$ \\
1998 Acar et al ${ }^{(1)}$ & 64 & $56(83 \%)$ \\
2002 Masahiro et al $^{(12)}$ & 26 & $24(91 \%)$ \\
${\text { 2002 } \text { Alves et al }^{(*)}}$ & 38 & $34(89.5 \%)$ \\
\hline
\end{tabular}

RA= Radial artery

(*) Current study

One of the greatest concerns, in respect to the RA, is the relationship to the intimal hyperplasia, chiefly, when anastomosed directly in the ascending aorta. This has been related with the structural and histological characteristics of the RA, leading to ischemia of the vessel wall and consequently, intimal proliferation, mainly when exposed to hemodynamic stress, caused by the acute increase in the $\Delta \mathrm{P} / \Delta \mathrm{T}$, present in the initial portion of the aorta [14]. For this reason, some authors have defended proximal anastomosis of the graft of the RA in the vascular region with the lowest $\Delta \mathrm{P} / \Delta \mathrm{T}$, such as the LITA $[9,14]$. Nevertheless, the study by Gaudino et al. [15] demonstrated that the RA, anastomosed on the ascending artery, presents with a vasodilation capacity depending on the endothelium after the injection of acetylcolin at one to five post-operative years which was not inferior to the LITA with an angiographic aspect demonstrating no lesions of the RA.

Despite of favorable angiographic images until now, it is impossible to say that there is no intimal lesion of the RA. For this, there is a necessity of histologic or endovascular echograms [15]. Costa et al. [16] reported two cases suspected of having atherosclerotic lesions in 28 grafts studied at five years after surgery.

In relation to the spasms of the RA an incidence of 11 $(28.9 \%)$ grafts with spasms was observed. However, in early studies of 38 grafts, $64 \%$ (7 grafts) presented with type I spasms (spasms $<50 \%$ of the diameter of the vessel and local), which could have been provoked by the catheter during angiography. A small percentage presented more significant spasms, local narrowing or diffuse narrowing of greater than $50 \%$ of the diameter of the vessel. This was observed in both the RA and LITA grafts, probably caused by competitive flow, as, during the early study, the coronary arteries were not seen with significant lesions, which, probably, caused the occlusion of some of the arterial grafts. We did not graft coronary arteries with arterial grafts which presented with lesions of less than $70 \%$ or with very bad distal flow. This may have occurred due to misinterpretation 
of the coronary angiogram or spasms of the coronary artery at the time of the study $[17,18]$.

The use of calcium canal blockers is controversial in the literature $[19,20]$, although we believe that the use of some type of vasodilator is necessary in the immediate postoperative period. This is because the incidence of spasms, in this period, is frequent with the RA being a muscular conduit with a strong tendency. The hyper-spastic characteristics of the RA tend to reduce over the time. This fact is demonstrated when the primary vasoconstrictor reaction of the conduit, after endovenous infusion of serotonin, is significantly reduced in the mid-term followup, and it is not different from the LITA despite the histological and biological differences between the two.

This confirmation is according to observations that the continuation of calcium canal blocker therapy, one year after the surgery, did not influence the clinical state of the patient and in the angiographic result of the RA [21].

Probably, early failure of the RA graft occurs due to intima lesion during dissection, prolonged spasms caused by competitive flow (lesion less than $70 \%$ in the coronary artery) or a bad distal flow [22,23]. The RA should not be used when there is inadequate blood flow to the hand after the capillary perfusion test, its calcification, renal failure (the patient may require a fistula for hemodialysis), a lesion less than $70 \%$ of the coronary artery, bad distal flow in the coronary artery and, in some professionals such as painters, musicians and surgeons.

\section{CONCLUSION}

The RA graft, for CABG presents good angiographic and patency aspects, both in the early and late studies, similar to the LITA in this evaluation period. However, only studies with a greater time of evolution can confirm its true benefits in CABG.

\section{BIBLIOGRAPHIC REFERENCES}

1. Reardon MJ, Conklin LD, Reardon PR, Baldwin JC. Coronary artery bypass conduits: review of current status. J Cardiovasc Surg (Torino) 1997; 38: 201-9.

2. Barner HB. Arterial grafting: techniques and conduits. Ann Thorac Surg 1998; 66 (5 suppl): 2-5; discussion S25-8.
3. Loop FD, Lytle BW, Cosgrove DM, Stewart RW, Goormastic $\mathrm{M}$, Williams GW et al. Influence of the internal-mammaryartery graft on 10-year survival and other cardiac events. N Engl J Med 1986, 314: 1-6.

4. Cameron A, Davis KB, Green G, Schaff HV. Coronary bypass surgery with internal-thoracic-artery grafts: effects on survival over a 15-year period. N Engl J Med 1996; 334: 216-9.

5. Pick AW, Orszulak TA, Anderson BJ, Schaff HV. Single versus bilateral internal mammary artery grafts: 10-year outcome analysis. Ann Thorac Surg 1997; 64: 599-605.

6. Carpentier A, Guermonprez JL, Deloche A, Frechette C, DuBost C. The aorta-to-coronary radial artery bypass graft: a technique avoiding pathological changes in graft. Ann Thorac Surg 1973; 16: 111-21.

7. Curtis JJ, Stoney WS, Alford Jr. WC, Burrus GR, Thomas Jr. CS. Intimal hiperplasia: a cause of radial artery aortocoronary bypass graft failure. Ann Thorac Surg 1975; 20: 628-35.

8. Fisk RL, Brooks CH, Callaghan JC, Dvorkin J. Experience with the radial artery graft for coronary artery bypass. Ann Thorac Surg 1976; 21: 513-8.

9. Acar C, Jebara VA, Portoghese M, Beyssen B, Pagny JY, Grare $\mathrm{P}$ et al. Revival of the radial artery for coronary artery bypass grafting. Ann Thorac Surg 1992; 54: 652-60.

10. Penna A, Barros R, Alves S, Albuquerque D, Pelloso E, Labruni A et al. Estudo angiográfico pós-operatório de pacientes submetidos a revascularização miocárdica com artéria radial. In: $24^{\circ}$ Congresso Nacional de Cirurgia Cardíaca; 1997; Campo Grande. Anais. São Paulo: Sociedade Brasileira de Cirurgia Cardiovascular; 1997. p.64.

11. Acar C, Ramsheyi A, Pagny JY, Jebara V, Barrier P, Fabiani JM et al. The radial artery for coronary artery bypass grafting: clinical and angiographic results at five years. J Thorac Cardiovasc Surg 1998; 116: 981-9.

12. Ikeda M, Ohashi H, Tsutsumi Y, Hige K, Kawai T, Ohnaka M. Angiographic evaluation of the luminal changes in the radial artery graft in coronary artery bypass surgery: a concern over the long-term patency. Eur J Cardiothoracic Surg 2002; 21: 800-3.

13. Dauar RB, Barros Jr. N, Lima PRL, Kyiose AT, Leão LEV, Succi JE. Valor da oximetria de pulso na avaliação da perfusão da mão para retirada da artéria radial: o teste de Allen é satisfatório? Rev Bras Cir Cardiovasc 1998; 13: 198-201.

14. Calafiore AM, Teodori G, Di Giamnarco G, D’Annunzio E, Angelini R, Vitolla G et al. Coronary revascularization with the radial artery: new interest for an old conduit. J Card Surg 1995; 10: 140-6. 
15. Gaudino M, Glieca F, Trani C, Lupi A, Mazzari MA, Schiavoni $\mathrm{G}$ et al. Midterm Endothelial function and remodeling of radial artery grafts anastomosed to the aorta. J Thorac Cardiovasc Surg 2000; 120: 298-301.

16. Costa FDA, Costa IA, Sardetto E, Scneider R, Lacerda G, Veiga $S$ et al. Emprego da artéria radial na revascularização do miocárdio. In: $29^{\circ}$ Congresso Nacional de Cirurgia Cardíaca: 2002; Natal. Anais. São Paulo: Sociedade Brasileira de Cirurgia Cardiovascular; 2002. p.79.

17. Dallan LA, Oliveira SA, Lisboa LA, Platania F, Jatene FB, Iglézias JCR et al. Revascularização completa do miocárdio com uso exclusivo de enxertos arteriais. Rev Bras Cir Cardiovasc 1998; 13: 187-93.

18. Barlem AB, Saadi EK, Gib MC, Manfroi WC. Enxertos arteriais na cirurgia de revascularização do miocárdio: papel da artéria radial. Rev Bras Cir Cardiovasc 2001; 16: 53-7.

19. Arena G, Abbate M. Is calcium antagonist administration necessary after aortocoronary-bypass with the radial artery? Ital Heart J 2000; 256-8.

20. Tatoulis J, Royse AG, Buxton BF, Fuller JA, Skillington PD, Goldblatt JC et al. The radial artery in coronary surgery: a 5year experience- clinical and angiographic results. Ann Thorac Surg 2002; 73: 143-8.
21. Possati G, Gaudino M, Alessandrini F, Luciani N, Glieca F, Trani $\mathrm{C}$ et al. Midterm clinical and angiographic results of radial artery used for myocardial revascularization. J Thorac Cardiovasc Surg 1998; 116: 1015-21.

22. Weinschelbaum EE, Macchia A, Caramutti VM, Machain HA, Raffaelli HA, Favaloro MR et al. Coronary revascularization surgery with arterial conduits: the technique, results and 4year follow-up in 1023 consecutive patients. Rev Esp Cardiol 2000; 53: 179-88.

23. Parolari A, Rubini P, Alamanni F, Cannata A, Xin W, Gherli T et al. The radial artery: which place in coronary operation? Ann Thorac Surg 2000; 69: 1288-94.

24. Chen AH, Nakao T, Brodman RF, Greenberg M, Charney, R, Menegus $M$ et al. Early postoperative angiographic assessment of radial grafts used for coronary artery bypass grafting. J Thorac Cardiovasc Surg 1996; 111: 1208-1212.

25. Da Costa FDA, Da Costa IA, Poffo R, Abuchaim D, Gaspar $\mathrm{R}$, Garcia L et al. Myocardial revascularization with the radial artery: a clinical and angiographic study. Ann Thorac Surg 1996; 62: 475-80.

26. Weinschelbaum EE, Gabe ED, Macchia A, Smimmo R, Suarez LD. Total myocardial revascularization with arterial conduits. J Thorac Cardiovasc Surg 1997; 114:911-916. 